\title{
Cones and craters on Mount Pavagadh, Deccan Traps: Rootless cones?
}

\author{
Hetu C Sheth*, George Mathew, Kanchan Pande, Soumen Mallick and \\ BALARAM JENA \\ Department of Earth Sciences, Indian Institute of Technology Bombay, Powai, Mumbai 400 076, India. \\ *e-mail: hcsheth@iitb.ac.in
}

Rootless cones, also (erroneously) called pseudocraters, form due to explosions that ensue when a lava flow enters a surface water body, ice, or wet ground. They do not represent primary vents connected by vertical conduits to a subsurface magma source. Rootless cones in Iceland are well studied. Cones on Mars, morphologically very similar to Icelandic rootless cones, have also been suggested to be rootless cones formed by explosive interaction between surface lava flows and ground ice. We report here a group of gentle cones containing nearly circular craters from Mount Pavagadh, Deccan volcanic province, and suggest that they are rootless cones. They are very similar morphologically to the rootless cones of the type locality of Mývatn in northeastern Iceland. A group of three phreatomagmatic craters was reported in 1998 from near Jabalpur in the northeastern Deccan, and these were suggested to be eroded cinder cones. A recent geophysical study of the Jabalpur craters does not support the possibility that they are located over volcanic vents. They could also be rootless cones. Many more probably exist in the Deccan, and volcanological studies of the Deccan are clearly of value in understanding planetary basaltic volcanism.

\section{Introduction: Mount Pavagadh, Gujarat}

The Deccan Traps of India constitute one of the finest and best-exposed continental flood basalt (CFB) provinces of the world, with a presentday areal extent of $5 \times 10^{5} \mathrm{~km}^{2}$ and an original extent estimated to be at least thrice as much (e.g., Wadia 1975). This CFB province is made up largely of subalkalic, tholeiitic basalt lavas, but strongly undersaturated-alkalic and felsic rock types, and regional dyke swarms of mafic and other compositions, are exposed in parts of the province such as the western Indian rifted margin and the Narmada-Satpura-Tapi rift zone (e.g., Mahoney 1988). Pahoehoe basalt flows constitute a large volume of the Deccan lavas (Keszthelyi et al 1999; Bondre et al 2004). Very few feeder dykes or eruptive vents have however been identified in the Deccan province.
Mount Pavagadh (829 m, figure 1), with one of the holiest shrines of the Hindus at its summit, is an imposing mountain in Gujarat made up of Deccan lavas and surrounded by Precambrian basement rocks. A modern-type geochemical, petrogenetic and stratigraphic study of the lava pile forming the mountain is lacking, but considerable petrological diversity is known: a thick sequence of mafic-intermediate lavas (mostly trachyandesite, basalt and some picrite/ankaramite) is capped by a thick rhyolitic flow (Chatterjee 1961). The mountain is surrounded by smaller hills, some of which apparently represent individual satellite vents. Rhyolite outcrops, and volcanic breccia deposits with clear quaquaversal dips, are seen in these hills. Here we describe the shallow cones with craters that are found on the uppermost mafic lava flow of Mount Pavagadh, below the summit rhyolite. We assume a general familiarity on the part of the reader with basic

Keywords. Deccan volcanism; Iceland; Mars; Pavagadh; rootless cones; pseudocraters. 


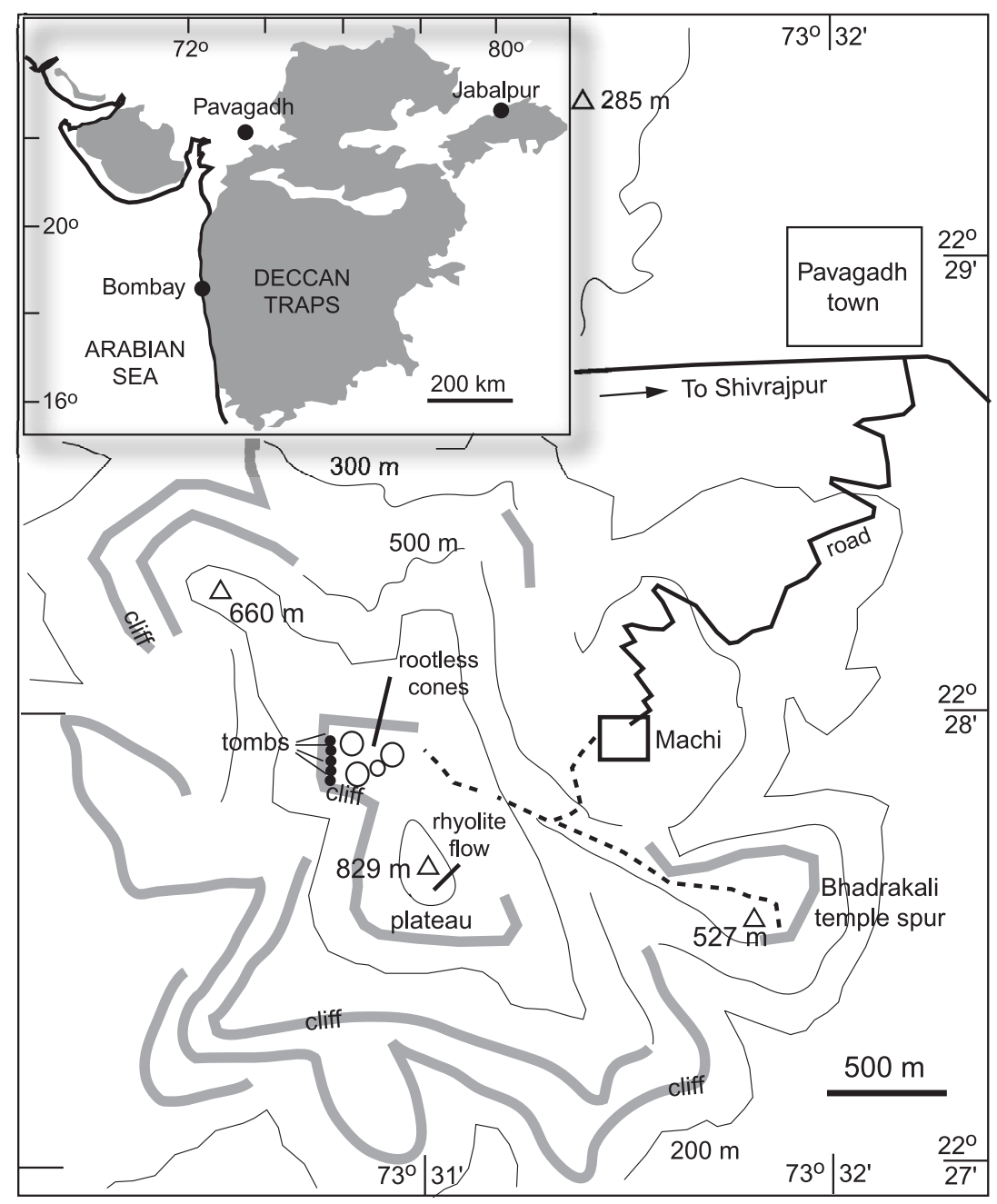

Figure 1. Topographic sketch-map of mount Pavagadh. Thick grey lines are near-vertical cliffs. The pilgrim route from Machi to the summit is shown as a dashed line. The rootless cones shown are schematic only. Inset shows the main outcrop of the Deccan flood basalt province in western and central India (shaded), and the locations of Pavagadh, Jabalpur, and Bombay.

volcanic landforms and volcanological terminology, and recommend an informative and nicely illustrated website managed by Vic Camp, located at www.geology.sdsu.edu/how_volcanoes_work.

The cones are found on the northwestern side of the Pavagadh plateau and have craters nestled within them (figures 1-3). The cones are nearly circular and $50-80 \mathrm{~m}$ wide, and very shallow in relation to their diameters (saucer-shaped), with raised rims that gently slope away from the craters. Although this shape is reminiscent of maars, they are undoubtedly somewhat eroded down since eruption of the Deccan lavas 65-60 million years ago. The ratio of the crater diameter to cone diameter is high $(>0.5)$, and the raised rims stand $<5 \mathrm{~m}$ above the crater floors. During our first field visit in December 2003, after the monsoon season, the largest crater contained a shallow lake, but the others were dry (figure 2). However, during our second field trip in June 2004, the lake in the large crater had dried up (figure 3) and the crater floor exposed soft reddish-brown soil. Indeed, without the crater lake these gentle cones with very shallow craters would most likely have been missed by us, as they nearly resemble an ordinary erosional landscape. This must be why, to the best of our knowledge, they have gone unreported by previous workers. We propose that they are a volcanic landform so far unidentified in India, namely, rootless cones.

\section{What are rootless cones, and how do they form?}

Many volcanic terrains all over the globe contain deposits and landforms that indicate interaction of lava, or magma, with surface or near-surface water. Phreatic is the term used for steam explosions resulting from conversion of water to steam due to magmatic heat, but if juvenile magma is 


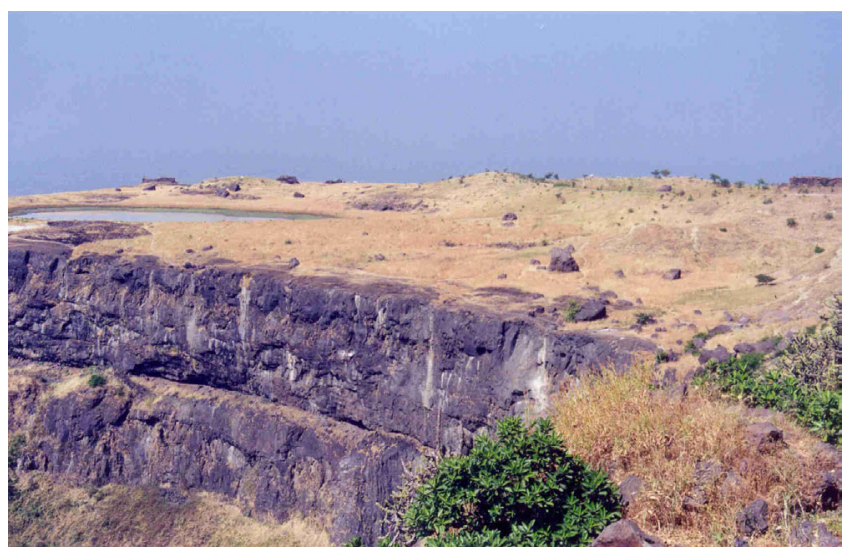

Figure 2. View of the cliffs and the plateau NW of the rhyolite (see figure 1) showing a nearly circular, shallow crater lake at left, a large rootless cone (dry) at right, and a much smaller one between these two. Note how the low rim of the large, dry rootless cone gently slopes away from it. Bushes and small trees on the rim provide a scale. The cliff face clearly exposes two distinct basalt flows. December 2003.

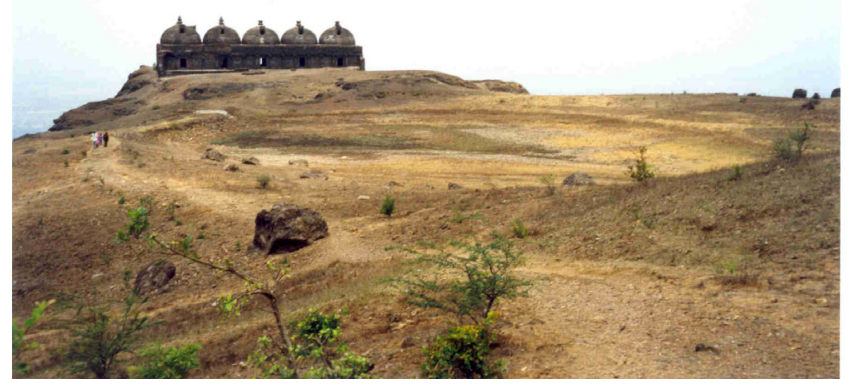

Figure 3. View (looking west) of the large crater with the dried-up shallow lake. The maximum depth of the water would have been about a metre only. People at left for scale. June 2004.

also thrown out of a volcanic vent besides steam and fragments of the country rock, the explosions are described as phreatomagmatic. Sheridan and Wohletz (1983) suggest hydrovolcanism as a general term for eruptive phenomena generated by the interaction of magma or magmatic heat with an external source of water, such as a surface water body or an aquifer, and hydrovolcanic processes occur at volcanoes of all sizes ranging from small phreatic craters to huge calderas, and even within hydrothermal zones related to plutons a few kilometres deep (Sheridan and Wohletz 1983).

Rootless cones are hydrovolcanic cones, made up of spatter, scoria, and ash, that form in and rest directly on tube-fed, inflated pahoehoe lava flows (for a model of formation of inflated pahoehoe flows, see Self et al 1997, 1998). Rootless cones form when lava flows interact with surface or near-surface water and the resulting mild explosions produce scoria and spatter that accumulate to form small cones around the explosion spots (Thorarinsson 1953). Typical locations where this happens are stream or river beds, lakes, or watersaturated sediments. The typical feature of rootless cones is internal stratification with reverse grading (coarser material toward the top), and the cones are capped with welded spatter, which sequence indicates decreasing explosivity during the course of their formation, arguably due to volatile depletion. A single cone is usually the result of several explosions attendant upon rapid groundwater recharge (Thordarson et al 1992; Thordarson and Höskuldsson 2002).

A rootless cone may form when lava flowing through an internal pathway through a lava flow (a lava tube) presses down into the underlying, lower-density, water-saturated sediment (figure 4a). Cracks develop in the lower lava crust and bring about contact of and explosive interaction between the lava and the water-saturated sediment. When an explosion occurs (figure 4b), further lava flow movement (and further rootless cone formation in the downflow direction) is halted, but more rootless cones can form upflow, and along the new lava tube network that progressively develops (Thordarson 2000; Thordarson and Höskuldsson 2002; Bruno et al 2004). Rootless cones, thus, are not primary magmatic vents directly connected to a subsurface magma source, and for this reason have also been termed "pseudocraters". The term is however, erroneous, as there is nothing "pseudo" about these craters which themselves are quite real (Th. Thordarson, pers. comm., 2004).

Thorarinsson (1953) was the first to show unequivocally that rootless cones in Iceland were formed by explosive interaction between lava and surface water, though the cones were described by several workers before him. The mechanism proposed by him for rootless cone formation was essentially a "static" one, in that it envisaged lava advance over a waterlogged substrate and vapourization of the water by purely conductive means. When the vapour pressure exceeded the overburden pressure, an explosion would result. The model was also based on simple cooling of an instantaneously emplaced flow unit and did not consider continued recharge of lava to the explosion site via preferred pathways (such as lava tubes) in the flow, and repeated explosions. In contrast to the static model, Thordarson (2000) proposed a "dynamic" heat transfer model which envisaged physical mixing of lava and substrate sediments, and resulted in highly efficient heat transfer and vapourization of the water and thereby thorough fragmentation of the lava and ejection of the fragments out of the explosion site. For this model to work, lava must 

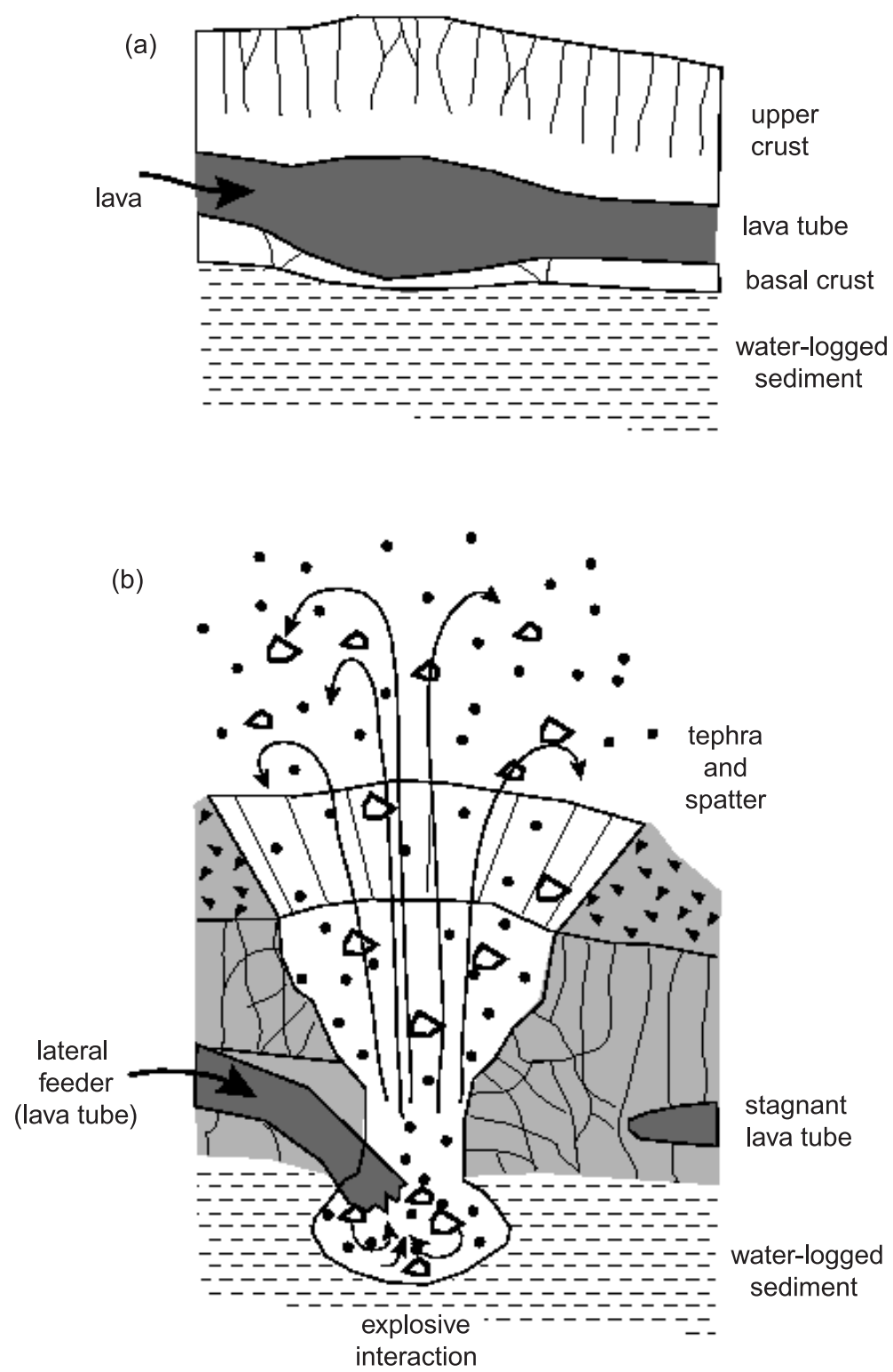

Figure 4. Proposed mechanism for rootless cone formation. (a) Lateral lava feeder (lava tube) supplies lava to the flow front, and the lava presses into the waterlogged sediment and cracks develop in the basal crust of the tube. (b) Physical mixing of the lava and waterlogged sediment causes a rootless eruption. (Simplified from Fagents and Thordarson (2004) and Bruno et al (2004))

continuously mix with the substrate, and for this, lava must be able to move continuously through the flow field and feed into the explosion site. This can be the case for a tube-fed, inflating pahoehoe lava flow (figure 5; see Fagents and Thordarson 2004).

\section{Rootless cones in Iceland}

Iceland is a large and entirely volcanic island, and the only emergent part of the global midocean ridge system (figure 6). Icelandic rootless cones typically exhibit a well-bedded basal unit of glassy ash to lapilli scoria, grading upward into a crudely-bedded sequence of spatter-rich material.
Icelandic rootless cones also do not show any postformational shearing, indicating that they were formed on a stationary upper crust of the lava. This means that lava was fed through internal pathways or lava tubes to the site of explosive interaction (Thordarson 2000). Rootless cones from the type locality around lake Mývatn in northeastern Iceland (figure 6) look very similar to the Pavagadh cones (see figures 1 and 5 of Greeley and Fagents 2001, and p. 176 of Scarth and Tanguy 2001). The Mývatn rootless cones are raised-rim depressions ranging in diameter from a few metres to $>100 \mathrm{~m}$ and are as deep as $15 \mathrm{~m}$ (measured from the rim crest). They are circular or elliptical in plan, and the craters are either centred 

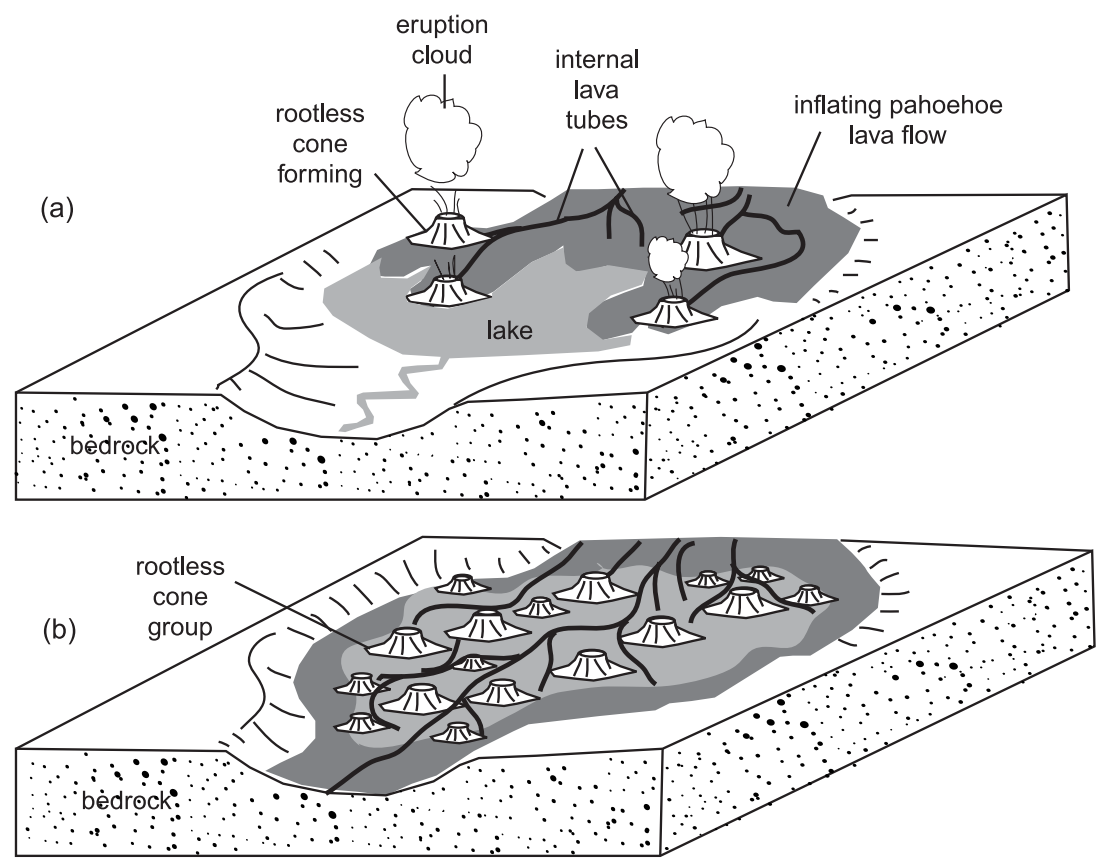

Figure 5. (a) A tube-fed lava flow partly covers a lake basin and thickens by inflation, and lava-water-sediment interaction at the flow front and along cracks in the tube floors produce several rootless eruptions. (b) A fully developed rootless cone group eventually results. Simplified from Thordarson and Höskuldsson (2002) and Fagents and Thordarson (2004).

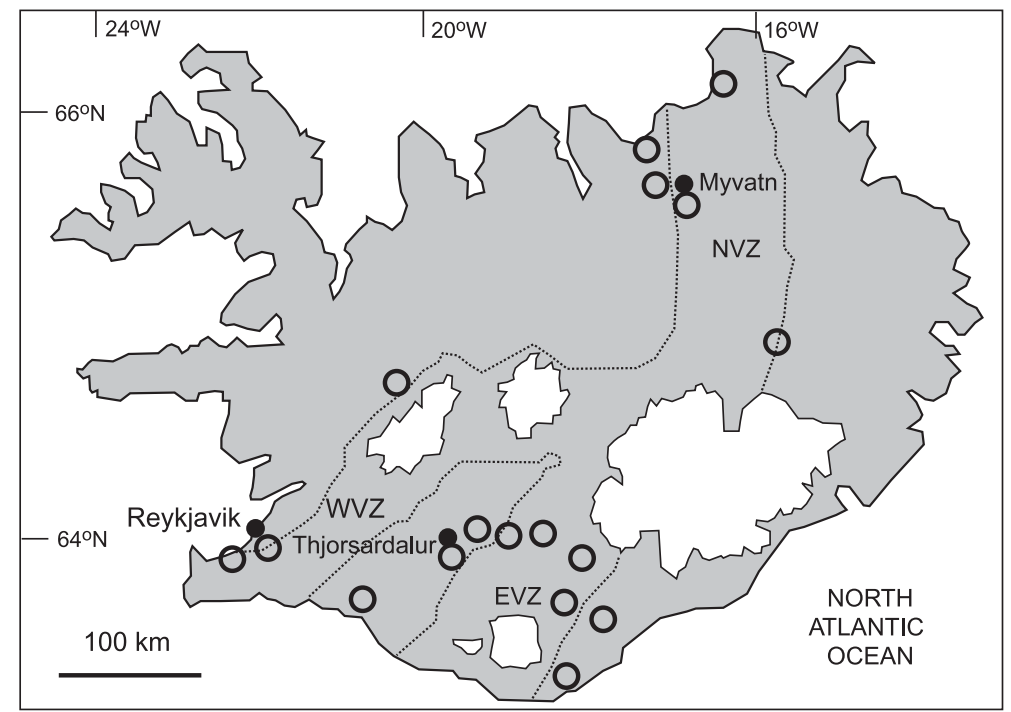

Figure 6. Sketch map of Iceland showing the locations of rootless cone fields (open circles), after Greeley and Fagents (2001) and Fagents and Thordarson (2004). Dotted lines mark the neovolcanic rift zones: NVZ (Northern Volcanic Zone), WVZ (Western Volcanic Zone), EVZ (Eastern Volcanic Zone). White areas are ice caps.

within the cones or offset. Many of the cones and craters stand "shoulder-to-shoulder" with overlapping ejecta deposits, which is also what we see at Pavagadh.

One of us (HCS) has field-tripped in Iceland and seen a major rootless cone field (several hundred individuals) near Thjórsardalur, south-central Iceland (figure 6). These cones are quite different in form from the Mývatn and Pavagadh cones, but are similar to those from the Álftaver district of southeastern Iceland described by Greeley and Fagents (2001) (see their figure 8). The Thjórsardalur and Álftaver rootless cones are smaller cones (generally $<50 \mathrm{~m}$ in diameter) that are steeper and more conical, and have either very small craters at the top or no craters at all. Different rootless cone fields can have a great variety of size and shape of individual cones: the ratio of crater diameter to cone 
diameter is variable, flanks of the cones can be concave upward or convex upward, and a great range of cone spacing exists. These characteristics, according to Greeley and Fagents (2001), can be related to the environment of their formation: the Mývatn rootless cones, with close spacing, formed in a lake basin with a presumably abundant supply of water, whereas the much more widely spaced cones of the Álftaver district formed along valleys and braided river systems where the supply of water was more limited.

\section{Rootless cones on Mars}

The planet Mars is very similar to Earth in many respects, and the Martian surface is rich in volcanic landforms. Olympus Mons on Mars, with a height of $25 \mathrm{~km}$ over the surrounding plains and a basal diameter of $600 \mathrm{~km}$, is the largest volcano in the Solar System (e.g., Head and Coffin 1997).

Lanagan et al (2001), based on high-resolution Mars Orbiter Camera (MOC) images, have reported the presence of clusters of small cones in several areas (the Cerberus plains, Marte Valles, and the Amazonis Planitia) near the Martian Equator. These cones are similar in size, morphology, and geological setting to the larger of the Icelandic rootless cones, and therefore Lanagan et al (2001) have suggested that the Martian cones are rootless cones. They were able to rule out alternative explanations such as impact craters or sedimentary mud volcanoes for the Martian cones based on several lines of evidence. For example, these cones clearly sit on the tops of lava surfaces, do not appear to have lavas issuing from them, and are grouped in clusters with no obvious alignments. The cones range in size from $20 \mathrm{~m}$ to $300 \mathrm{~m}$ in basal diameter. They have large summit craters with diameters about half as wide as the bases. The dimensions are thus similar to those of the larger and more explosive of the Icelandic rootless cones (less explosive cones have smaller and narrower summit craters). The Pavagadh cones are closely similar, with crater diameters more than half as wide as the cone diameters, suggesting considerable explosive power. The Martian cones form clusters and each cluster includes a few to hundreds of cones, and there are no strong cone alignments suggestive of an underlying fissure vent. The Icelandic rootless cones also do not show preferred alignments, and there is no evidence at Pavagadh either of any. The surface on which the Martian cones rest is formed of platy-ridged lava, and this has been interpreted as rubbly pahoehoe which forms when the upper crust of inflated flow gets broken up and remobilized (Keszthelyi and Thordarson 2000).
Based on impact crater size-frequency relationships (Hartmann 1999), it is known that the surfaces upon which the Martian cones rest are no older than 10 million years. The profound implications of this for planetary science are that equatorial ground ice or ground water must have been present near the Martian surface in its recent geological history, and it may exist in the uppermost layers of the Martian ground even today.

\section{The Pavagadh cones: Why rootless cones?}

Two other types of volcanic cones or craters, besides rootless cones, are not eruptive vents. Littoral cones, one of these types, form when lava flows enter the sea. They are well known from Hawaii (e.g., Macdonald et al 1983; Mattox and Mangan 1997). The other type is pit craters which are nearly circular or elliptical craters that form by subsidence. Pit craters are common on the Big Island of Hawaii and are particularly well seen along the Chain of Craters Road on the active volcano Kilauea. Up to about a kilometre in diameter, these form in the roofs of large lava tubes as the magma flowing underneath dislodges the roof rocks. Usually no lava or pyroclastic material is emitted from the pit craters during their formation, though surface lava flows have been seen to flow into already existing pit craters and make lava ponds (Macdonald et al 1983). The Pavagadh cones are obviously not littoral cones, and do not look like pit craters either.

We believe that the Pavagadh cones are rootless cones because:

- they are similar in size to rootless cones known from Iceland and elsewhere;

- they have a strong morphological resemblance to the rootless cones from the type locality of Mývatn, northeastern Iceland;

- the various cones are overlapping, and stand "shoulder-to-shoulder" (figure 2);

- they have not produced lava flows themselves (volcanic cones that are eruptive vents, e.g., cinder cones, often have lava flows issuing from them);

- they occur on a basalt flow, are surrounded by the lava flow and are not deformed by motions of the lava, i.e., they formed subsequent to the host lava flow after its surface crust had frozen - obviously the lava that formed scoria by mixing with water was fed to the lava flow internally, consistent with observations elsewhere in the world;

- though the area left today after erosion through 65-60 million years is relatively small, the 
Pavagadh cones have an apparently random distribution, similar to that known for Icelandic and Martian rootless cones (Bruno et al 2004; Lanagan et al 2001).

There is no evidence for a sedimentary substrate of the topmost basalt lava flow (in which the cones occur) at Pavagadh; however, we envisage that shallow lakes had formed on the immediately underlying flow. Subaqueous eruptions are well known from the Deccan (e.g., pillow lava and hyaloclastite in Bombay, see Sukheswala and Poldervaart 1958; Sethna 1981). If we are correct in our identification of the Pavagadh cones and craters as rootless cones, then this is the first time they are being identified in Deccan geology and, as far as we know, in Indian geology.

\section{The Jabalpur craters, northeastern Deccan Traps: Rootless cones?}

Srinivasan et al (1998) discovered a group of three nearly circular phreatomagmatic craters, close to the village Barela $15 \mathrm{~km} \mathrm{SE}$ of Jabalpur (figure 1). These craters have diameters of $60-80 \mathrm{~m}$ and very low relief (only 1-2 $\mathrm{m}$ above the ground surface) and are covered by $\sim 1 \mathrm{~m}$ thick soil. The vents are surrounded by compact basalt. The large crater on Pavagadh (figure 3) entirely matches this description (see their figure 2). The Jabalpur vents themselves are filled with volcanic tuff (lapilli set in coarse to fine ash) below the soil, and the tuff is at least $2 \mathrm{~m}$ thick (base not reached during pitting). The lapilli are mainly basaltic glass, but felsic lava fragments are also found. The tephra show poor sorting and bedding. We could not carry out trenching or pitting on Pavagadh and hence do not have a depth control, but the rim of one of the craters is made up of spatter-like material.

Srinivasan et al (1998) considered these features as phreatomagmatic eruptive vents - either cinder cones, tuff rings or maars. They stated that these centres could not be tuff rings because tuff rings are much larger, and the features could not be maars because they do not contain accidental xenoliths (of the basement rocks). They interpreted these vents as cinder cones instead, and argued that the subdued relief may be the result of fluidrich basaltic volcanism and post-eruption erosion. Their description of these features matches our own observations at Pavagadh, i.e., we consider it highly probable that the Jabalpur craters are rootless cones. This means, of course, that although phreatomagmatic, they are not eruptive vents as Srinivasan et al (1998) imagined them to be. The absence of xenoliths of crustal (or mantle) rocks in the ejecta is therefore hardly surprising.
A new study of these Jabalpur craters has just become available: Srivastava et al (2004) have carried out a gravity and magnetic survey of them and found a Bouguer anomaly variation of 1.2 to $2 \mathrm{mGal}$ in a 1.5 - $\mathrm{km}$-long profile and total field magnetic anomaly of the order of -900 to $1400 \mathrm{nT}$. Srivastava et al (2004) find no evidence for deep-seated high-density material underlying these craters, and no isolated or elliptical magnetic anomalies. By using the Werner deconvolution technique they obtain depths to the granitic basement under the three craters as 51.7, 57.6 and $75 \mathrm{~m}$, and conclude that their gravity and magnetic study does not support the view that these craters are vents. We think that the rootless cone explanation for the Jabalpur craters satisfies all data and observations.

\section{Discussion and conclusions}

What alternative interpretations of the Pavagadh craters are possible? Earlier we considered the Pavagadh cones to be not rootless cones but maars, because of their very low relief and saucer-like shape, and because of the experience of one of us (HCS) with the Thjórsardalur rootless cones in southern Iceland that are morphologically very different. However, maars imply primary magmafeeding vents, and are rarely $<1 \mathrm{~km}$ wide (S. Self, pers. comm., 2004), and as noted, rootless cones have a great variety of shapes and sizes. Some of the largest rootless cones in Iceland, $500 \mathrm{~m}$ in diameter, have tuff cone morphology and are entirely made up of ash to fine-grained lapilli deposits indicating a high degree of magma fragmentation (i.e., efficient magma-water interaction) (Thordarson et al 1992; Thordarson 2000; Thordarson, pers. comm., 2004).

S. Self (pers. comm.) also pointed out to us the possibility that the Pavagadh craters may be related to subsidence along circular-annular joint fractures in the basalt. Such structures are seen in the Columbia River Basalt province of the northwestern U.S.A. and are not well understood. However, the Pavagadh craters are themselves parts of shallow cones, and these cones match the characteristics of rootless cones so well that we cannot conceive of a better explanation.

As a final statement, we think that rootless cone groups should be abundant in the Deccan, given its abundance of tube-fed, inflated pahoehoe lava flows. Rootless cones are known from other flood basalt provinces of the world, such as the Columbia River province (Thordarson and Self 1998). Given the fundamental role of basaltic volcanism in the chemical and thermal evolution of the terrestrial planets (Basaltic Volcanism Study Project 1981), 
volcanological studies of the Deccan should provide valuable insights into planetary development.

\section{Acknowledgements}

HCS, GM and KP thank the Industrial Research and Consultancy Centre (IRCC), IIT Bombay, for supporting this work. Sveinn Jakobsson and Gillian Foulger led the field excursions in southern and south-central Iceland in which HCS participated as a delegate in the GSA Penrose Conference 'Plume IV: Beyond the Plume Hypothesis' (2003). Sarah Fagents kindly supplied a preprint, and Steve Self, Ken Wohletz, and Sheila Seaman provided helpful reviews and discussions on an earlier version of this manuscript. Self's very critical review of that version resulted in substantial modification and clarification of our ideas. Thor Thordarson provided some very helpful comments on the revised version.

\section{References}

Basaltic Volcanism Study Project 1981 Basaltic Volcanism on the Terrestrial Planets (New York: Pergamon Press)

Bondre N R, Duraiswami R A and Dole G 2004 Morphology and emplacement of flows from the Deccan volcanic province, India; Bull. Volcanol. 66 29-45

Bruno B C, Fagents S A, Thordarson T and Baloga S M 2004 Spatial analysis of rootless cone groups on Iceland and Mars (abstract); Lunar Planet. Sci. XXXV 1368

Chatterjee S C 1961 Petrology of the lavas of Pavagad Hill, Gujarat; J. Geol. Soc. India 2 61-77

Fagents S A and Thordarson Th 2004 Rootless volcanic cones in Iceland and on Mars. In: The Geology of Mars: Evidence from Earth-Based Analogues (eds) M G Chapman and I P Skilling; Cambridge Univ Press (in press)

Greeley R and Fagents S A 2001 Icelandic pseudocraters as analogs to some volcanic cones on Mars; J. Geophys. Res. $10620527-20546$

Hartmann W K 1999 Martian cratering VI: crater count isochrons and evidence for recent volcanism from Mars Global Surveyor; Meteor. Planet. Sci. 34 167-177

Head J W and Coffin M F 1997 Large igneous provinces: a planetary perspective. In: Large Igneous Provinces: Continental, Oceanic, and Planetary Flood Volcanism (eds) J J Mahoney and M F Coffin, AGU Geophys. Monogr. 100, 411-438

Keszthelyi L and Thordarson Th 2000 Rubbly pahoehoe: a previously undescribed but widespread lava type transitional between aa and pahoehoe (abstract); GSA Abst. Progr. 327

Keszthelyi L, Self S and Thordarson Th 1999 Application of recent studies on the emplacement of basaltic lava flows to the Deccan Traps. In: Deccan Volcanic Province (ed) K V Subbarao; Geol. Soc. India Mem. 43 pp 485-520
Lanagan P, McEwen A S, Keszthelyi L P, Thordarson Th 2001 Rootless cones on Mars indicating the presence of shallow equatorial ground ice in recent times; Geophys. Res. Lett. 28 2365-2367

Macdonald G A, Abbott A T and Peterson F L 1983 Volcanoes in the Sea: The Geology of Hawaii 2nd edn. (Honolulu: University of Hawaii Press) 517 pp

Mahoney J J 1988 Deccan Traps. In: Continental Flood Basalts (ed) J D Macdougall; (Dordrecht: Kluwer Acad Publ) 151-194

Mattox T N and Mangan M T 1997 Littoral hydrovolcanic explosions: a case study of lava-seawater interaction at Kilauea volcano; J. Volcanol. Geotherm. Res. 75 1-17

Scarth A and Tanguy J-C 2001 Volcanoes of Europe (Oxford Univ Press) 241 pp.

Self S, Thordarson Th and Keszthelyi L 1997 Emplacement of continental flood basalt lava flows. In: Large Igneous Provinces: Continental, Oceanic, and Planetary Flood Volcanism (eds) J J Mahoney and M F Coffin, $A G U$ Geophys. Monogr. 100 381-410

Self S, Keszthelyi L and Thordarson Th 1998 The importance of pahoehoe; Ann. Rev. Earth Planet. Sci. 26 81110

Sethna S F 1981 Geology around Bombay — some intriguing problems. In: Deccan Volcanism (eds) K V Subbarao and R N Sukheswala; Geol. Soc. India Mem. 3 pp 8792

Sheridan M F and Wohletz K H 1983 Hydrovolcanism: basic considerations and review. In: Explosive Volcanism (eds) M F Sheridan and F Barberi, J. Volcanol. Geotherm. Res. 17 1-29

Srinivasan R, Jaffri S H, Rao G V and Reddy G K 1998 Phreatomagmatic eruptive centre from the Deccan Trap province, Jabalpur, central India; Curr. Sci. $74787-$ 790

Srivastava R P, Chattopadhyay S, Vedanti N and Dimri V P 2004 Gravity and magnetic studies over the circular geomorphic crater looking structures in the Narmada Traps, central India; J. Geol. Soc. India 64 97-102

Sukheswala R N and Poldervaart A 1958 Deccan basalts of Bombay area, India; Bull. Geol. Soc. Am. 69 14751494

Thorarinsson S 1953 The Crater Groups in Iceland; Bull. Volcanol. 14 3-44

Thordarson Th 2000 Rootless eruptions and Cone Groups in Iceland: products of authentic explosive water to magma interactions (abstract), Volcano-Ice Interactions on Earth and Mars 48.

Thordarson Th and Self S 1998 The Roza Member, Columbia River Basalt Group: A gigantic pahoehoe lava flow field formed by endogenous processes? J. Geophys. Res. 103 27411-27445

Thordarson Th and Höskuldsson A 2002 Iceland; Classic Geology in Europe 3 Terra Publishing, Harpenden, U.K. $200 \mathrm{p}$

Thordarson Th, Morrissey M M, Larsen G and Cyrusson H 1992 Origin of rootless cone complexes in S-Iceland. In: The 20th Nordic Geological Winter Meeting (eds) A Geirsdóttir, H Norddahl and G Helgadóttir, Icelandic Geoscience Society, Reykjavik, 169

Wadia D N 1975 The Geology of India. 4th edn. (New Delhi: Tata-McGraw Hill) 508 pp 